\title{
Career Development of South African KNOWLEDGE WORKERS
}

\author{
Roelof van Staden and Adeline du Toit
}

Centre for Information and Knowledge Management, University of Johannesburg

Accepted Aug 2010

\begin{abstract}
The demand for knowledge workers is on the increase, yet little is known about their career perceptions and attitudes. The objective of this article is to determine the factors affecting the career development of knowledge workers in South Africa. Part-time learners of a postgraduate course were used as a purposive sample and 82 completed questionnaires were received. The results of the online survey provide an interesting look at the unique career issues knowledge workers experience from a South African perspective. Issues identified dealt with the lack of importance placed upon organisational training, the lack of interest in temporary work assignments and the low importance placed on learning from mentors. Organisations need to take note of their reward structures as knowledge workers have indicated that promotions and rewards based on their knowledge is insufficient.
\end{abstract}

Key words: career perceptions; knowledge economy; knowledge workers

JEL D80, 83

1

\section{Introduction}

Knowledge is stored in the minds of knowledge workers, which means that organisations need to balance business needs against the needs of knowledge workers (Stokely, 2008:47) to ensure that organisational knowledge becomes a strategic asset in order to remain competitive and survive in the knowledge economy (Zack, 1999). Products, services and processes that create value are becoming more complex, requiring even more changes in the way organisational knowledge is managed. This result in changes in the way knowledge workers develop their careers. The knowledge economy is forcing knowledge workers to realise that multiple assignments, projects, jobs and possibly multiple careers are the norm. Even though the knowledge economy can be turbulent, successful knowledge workers are able to see new opportunities for themselves and society (Drucker, 2001:283).

The demand for knowledge workers is on the increase, yet little is known about their career perceptions and attitudes (Pringle \&
Mallon, 2003:839). The primary objective of this article is to determine the factors affecting the career development of knowledge workers in South Africa. The secondary objective is to determine via an empirical survey causes of career dissatisfaction and areas where career development is needed among South African knowledge workers. South Africa is becoming less competitive owing to lack of skills, for example the limited availability of knowledge workers such as engineers (Van Tonder, 2007). Van Tonder (2007) notes that South Africa is now ranked $50^{\text {th, }}$ out of 55 countries in the IMD World Competitiveness Yearbook from a previous best of $38^{\text {th }}$ place.

With only 44.6 per cent of skilled workers receiving any form of training, South Africa is not investing in the small knowledge worker population (Smith, 2008). If prosperity and even survival depend on knowledge worker productivity (Drucker, 1999:83), then organisations in South Africa need to address issues concerning knowledge workers. Reliance on knowledge workers creates interesting problems for South African organisations, as specialisation and dual career ladders are required to ensure that the 
knowledge residing in the minds of knowledge workers is not lost.

\section{2}

\section{Knowledge workers}

Bergeron (2003:58) defines knowledge workers as individuals who contribute to the intellectual capital of their organisation. The products or output of a knowledge worker is considered to be knowledge assets consisting of documentation, newsletters, online weblogs and other publications. Drucker (2002:238) defines knowledge workers from an individual's point of view. An individual with significant amounts of theoretical knowledge and learning constitutes a knowledge worker. Paton (2005:23) defines a knowledge worker as an educated individual in a specialist knowledge area. For the purpose of this article, a knowledge worker is seen as an individual that has considerable knowledge and learning in a specialist field.

Knowledge work is discretionary behaviour and activities that are performed by knowledge workers (Efimova, 2003:1; Schell, 2008:4). Information gathering, imagination, experimenttation, discovery and integration of knowledge within larger systems are all part of knowledge work (Myers, 1996:46). Technical skills, behavioural competencies and attitudes contribute to the knowledge work that is performed (Mercer, 2008).

\section{3}

\section{Demand for knowledge workers}

The ability of an organisation to attract and retain knowledge workers is central to its present and future success in the knowledge economy (Templer \& Cawsey, 1999:71). If one takes into account that knowledge workers will become the dominant group of workers in the future (Drucker, 2002:237), then knowledge workers will appear to have borderless, upward career mobility with the potential for failure or success. The growth in certain economic sectors, coupled with knowledge workers entering retirement, creates a unique demand for knowledge workers. Such growth requires knowledge workers to obtain formal education to enter these areas of knowledge work. Once knowledge workers enter these sectors, continuing education will be required to ensure that their knowledge is kept up to date. Such a scenario highlights the need for continuous learning of knowledge workers as knowledge rapidly becomes obsolete in knowledge organisations. The transition of knowledge workers from a young age to an older age requires succession planning to ensure that knowledge remains in organisations (Harman \& Brelade, 2000:31; Stovel \& Bontis, 2002:309). The increase in longevity of workers has created a unique problem for organisations. Knowledge workers can no longer perform the same kind of work for fifty years. Second careers after retirement are seen as ways to keep mentally fit (Drucker, 2002:249). Becoming a freelance worker, contractor or consultant also aids organisations, as new ideas and innovations can be brought into organisations as part of any knowledge worker's job (Drucker, 1999:86; Higgins \& Tap, 2008:35). Organisations should therefore adapt their knowledge management programmes to retain key expertise in an effort to reduce costs and develop new products and services (Stankosky, 2005:150).

\section{4}

\section{Career development of knowledge workers}

The period of the $1950 \mathrm{~s}$ to the $1980 \mathrm{~s}$ characterised traditional careers, as careers were seen as stable and predictable. Careers were a succession of related jobs arranged in a hierarchy of status levels through which people moved in an ordered and predictable sequence (Currie, Tempest \& Starkey, 2006:756). The organisation determined what constitutes career success, which was usually measured by promotions and increases in salary.

The changes in traditional organisational structures are forcing many individuals to change their view of a career, as the career options in flatter organisations are limited (Evans, 2003:180). The change of career type from a traditional hierarchical career to a 
career characterised by a lack of organisational support and boundaries has shifted the responsibility for career development away from organisations to individual knowledge workers (Currie et al., 2006:756). Myers (1996:184) and Tampoe (quoted by Carter \& Scarbrough, 2001:218) identified four key career motivators once a knowledge worker has moved beyond career entry. These four key motivators are personal growth, operational autonomy, task achievement and money.

Personal growth is the first key motivator and can be described as the opportunity for individuals to realise their potential through intellectual, personal and career development. Organisations need to address job design, assignments and career progress to provide meaningful and challenging work that will lead to personal growth for knowledge workers (Mercer, 2008). Knowledge acquisition forms part of personal development, leading to a sense of achievement and recognition of peers and ensures that workers grow as individuals and as professionals (Lin, Kuo, Ho \& Kuo, 2008:93; Svetlik \& Stavrou-Costea, 2007:197; Thite, 2004:33). Career development programmes need to offer career path design, mentoring, training, improving work environments and competitive compensation packages (Currie et al., 2006:760).

The stimulation and challenges provided by the job that a knowledge worker performs also contribute to personal growth. Knowledge workers like software developers desire challenging work and learning opportunities (Dovey \& White, 2005:253). People are motivated when they are interested in the job, even though they may find the status, perks or responsibility associated with it of little value.

Operational autonomy is the second key motivator and can be described as a work environment that allows knowledge workers to have control over the tasks that are assigned to them within the constraints of the organisational setting. The organisational culture and leadership influence the manner in which knowledge is managed (Mercer, 2008). Knowledge workers need a dynamic knowledge-based organisation to be able to define and direct their own jobs if they are to take responsibility for their tasks (Drucker, 1999:84; Myers, 1996:46). Organisational culture needs to align itself with the values and habits of knowledge workers to provide such a level of autonomy (Nemeth \& Nemeth in Nonaka \& Teece, 2001:101). The key to obtaining this level of autonomy lies in the level of flexibility a knowledge worker's manager will allow (Mercer, 2008).

Task achievement is the third key motivator and can be described as the sense of satisfaction that a knowledge worker gets from producing work of a high standard and quality that the individual feels proud of. Aligning the personal goals of knowledge workers with organisational goals will enable them to be motivated through task achievement to work towards common goals and not egotistic ones (Kelly, 2007:126). Another issue related to task achievement is the boredom associated with repetitive or less challenging tasks. Tasks need to be kept challenging in order to prevent boredom from reducing the sense of accomplishment that knowledge workers get from their working careers (Dovey \& White, 2005:253; Drucker, 2001:281).

The importance of financial compensation (the last motivating factor) may be less important for knowledge workers than traditional workers as job security for knowledge workers depends on the development of a body of knowledge and skills that they can transfer from one organisation to another (McGregor, Tweed \& Pech, 2004: 159). Money is seen as a reward for the contribution made by knowledge workers to the success of the organisation. Even though money cannot ensure the retention of knowledge workers, remuneration should be structured according to the way work is defined in the organisation and could include basic pay, incentives, benefits and retirement funds (Mercer, 2008). The study of money as a motivational factor has always featured prominently in career studies (Petroni \& Colacino, 2008:22). An interesting finding in this regard shows that male knowledge workers change jobs more often for higher pay than their female counterparts (Yang \& Lee, 2009:87). 
5

\section{Survey on career development of knowledge workers}

\subsection{Research methodology}

Knowledge workers are considered to be people with considerable theoretical knowledge and learning (Drucker, 2002:238). As such, knowledge workers are responsible for their own learning and development (Gottschalk, 2005:27), using diverse sources to obtain more information and knowledge. Even though knowledge workers may be educated in a specific knowledge area, they are continually learning (Paton, 2005:23). The knowledge economy requires knowledge workers to obtain new skills and talents (Waddock, 2007:544) in order to contribute to the organisation's competitive advantage (Drucker, 2002:124). Knowledge workers are thus considered to be individuals taking part in some form of learning, in order to increase their knowledge. The population for the empirical survey consists of all knowledge workers in South Africa and a sampling frame could not be established. The population thus needed to be more narrowly defined for the purposes of this research project. Part-time learners of a postgraduate course were used as a purposive sample to access the knowledge worker population. The respondents were all enrolled at the University of Johannesburg for the M.Com (Business Management) course. The respondents came from various backgrounds and educational levels.

An online survey was chosen as the research instrument and featured a welcoming page, attempting to gain the respondent's cooperation, providing instructions on how to complete the questionnaire and the approximate time it would take to complete (Zikmund, 2003:222). The questionnaire was divided into eight sections: biographical data, knowledge as seen from a career perspective, career motivators: career readiness, path, strategy and satisfaction. Each section was given a rating using a five-point Likert scale, in order to obtain a positive or negative response from respondents. The web address of the online survey was distributed via electronic mail to 266 respondents. Out of the 90 questionnaires completed, eight were unusable and 82 questionnaires were usable, which resulted in a response rate of 31 per cent.

The reliability of the research items was determined using Cronbach's alpha test (see Table 1), determining whether the measuring instruments are homogenous (Cooper \& Schindler, 2003:237).

\begin{tabular}{|l|c|}
\multicolumn{2}{c}{$\begin{array}{c}\text { Table 1 } \\
\text { Reliability }\end{array}$} \\
\hline \multicolumn{1}{|c|}{ Section } & Cronbach alpha \\
\hline Knowledge & 0.730 \\
\hline Knowledge development & 0.683 \\
\hline Career motivators & 0.725 \\
\hline Career readiness & 0.754 \\
\hline Career strategy & 0.874 \\
\hline Satisfaction & 0.896 \\
\hline
\end{tabular}

The reliability coefficient for each section is greater than 0.7 , indicating positive reliability, except for the section on knowledge development. The section on knowledge development has a Cronbach alpha of 0.683. The sections mentioned in Table 1 are thus considered to be reliable for the purpose of this survey.

\subsection{Findings}

\subsubsection{Biographical data}

The gender of the respondents that completed the online questionnaire was mostly male (69.5 per cent) with a low response rate from females (30.5 per cent). The age group 25 to 
40 provided most responses, with the number of responses from people older than 40 years tapering off to only two people older than 55 years. The demographic data are indicative of a broad range of knowledge workers and the area of specialisation of the respondents was predominantly the business and information technology fields. One respondent was in the educational field and the other two respondents in the logistics field. The length of employment indicates that knowledge workers are no longer content with lifelong employment with one organisation and 47.5 per cent of the respondents have worked for their current employer for less than three years. This correlates with the finding of Bergeron (2003:593).

\subsubsection{Knowledge}

The descriptive statistics related to knowledge as seen from a career perspective are shown in Table 2, with the results in percentages. The modal category for each option is shaded.

Table 2

Knowledge

\begin{tabular}{|l|c|c|c|c|c|}
\cline { 2 - 5 } \multicolumn{1}{l|}{} & $\begin{array}{c}\text { Totally } \\
\text { agree }\end{array}$ & Agree & Neutral & Disagree & $\begin{array}{c}\text { Totally } \\
\text { disagree }\end{array}$ \\
\hline $\begin{array}{l}\text { Knowledge is crucial in giving me a } \\
\text { competitive advantage in my career }\end{array}$ & $58.5 \%$ & $34.1 \%$ & $6.1 \%$ & $1.2 \%$ & $0.0 \%$ \\
\hline $\begin{array}{l}\text { My job requires more knowledge than it } \\
\text { ever did before }\end{array}$ & $47.6 \%$ & $32.9 \%$ & $17.1 \%$ & $2.4 \%$ & $0.0 \%$ \\
\hline $\begin{array}{l}\text { Knowledge is a key factor in any } \\
\text { decision made with regard to my career }\end{array}$ & $31.7 \%$ & $47.6 \%$ & $12.2 \%$ & $8.5 \%$ & $0.0 \%$ \\
\hline $\begin{array}{l}\text { The higher my level of knowledge, the } \\
\text { more rewards I will receive }\end{array}$ & $24.4 \%$ & $40.2 \%$ & $24.4 \%$ & $8.5 \%$ & $2.4 \%$ \\
\hline
\end{tabular}

Table 2 indicates that knowledge is seen as a key component in a knowledge worker's career, with more than 58 per cent of the respondents indicating that they totally agree that knowledge is crucial to providing knowledge workers with a competitive advantage in their careers. The importance placed upon knowledge in career decisions is consistent with knowledge workers creating a competitive advantage in the knowledge economy through the use of knowledge (Harman \& Brelade, 2000:2). The amount of knowledge required by knowledge workers' jobs is indicative of the amount of information required by knowledge workers in the knowledge economy (Bontis, 2001:3; Deng: 174).

\subsubsection{Knowledge development}

Respondents were asked what steps they have taken to increase their knowledge to further their career aspirations. The descriptive statistics related to knowledge development as seen from a career perspective are shown in Figure 1. 
Figure 1

Knowledge development

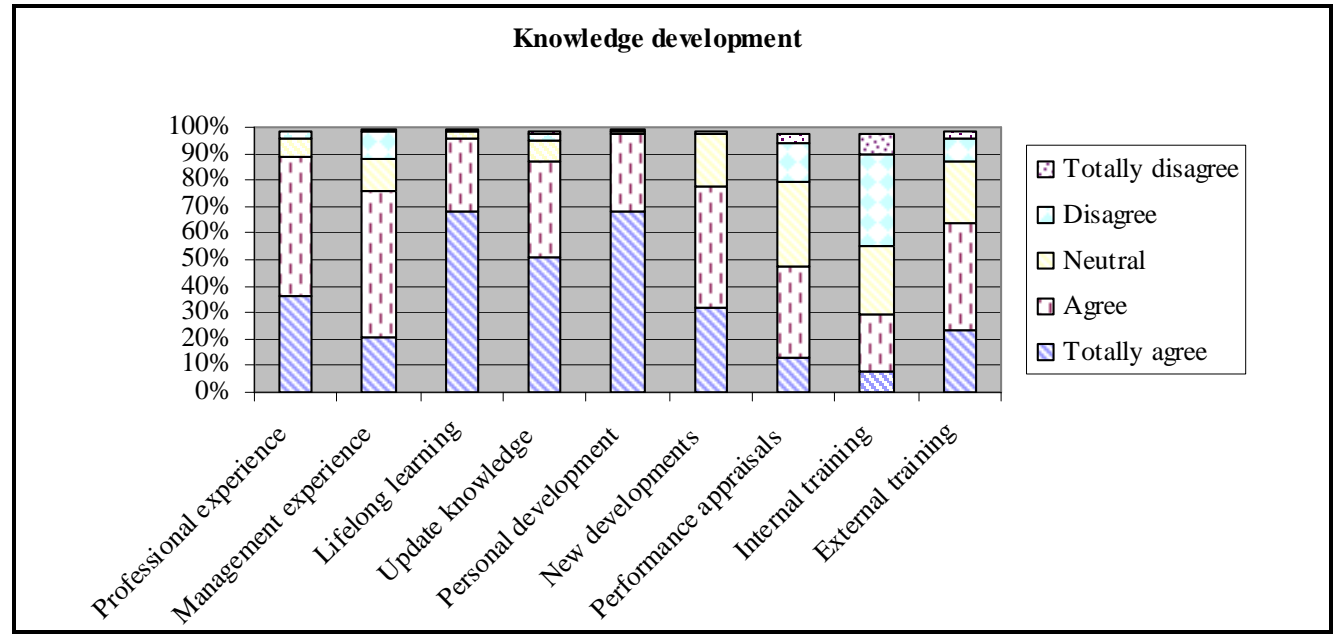

Figure 1 indicates that knowledge development is required by knowledge workers as 68.3 per cent of the respondents totally agree that lifelong learning is important, which agrees with learning being a lifelong process (Alley, 1999:189, Drucker, 2001:305). The majority of the respondents (68.3 per cent) also totally agree that they are responsible for their own personal development, as it seems that employers are no longer willing to take this responsibility (Thite, 2004:32). The low number of respondents ( 0.08 per cent) who totally agree that they mainly use internal training to develop their knowledge is indicative of the low investment that South
African organisations make in knowledge workers, according to Smith (2008). The number of respondents ( 0.23 per cent) who totally agree that they primarily use external training to develop their knowledge should be a cause of concern for organisations as this could indicate that organisational training and development programmes are not living up to the expectations of knowledge workers.

\subsubsection{Career motivators}

Respondents were asked to identify factors that motivate them in their careers as knowledge workers. The descriptive statistics related to career motivators are shown in Figure 2:

Figure 2

Career motivators

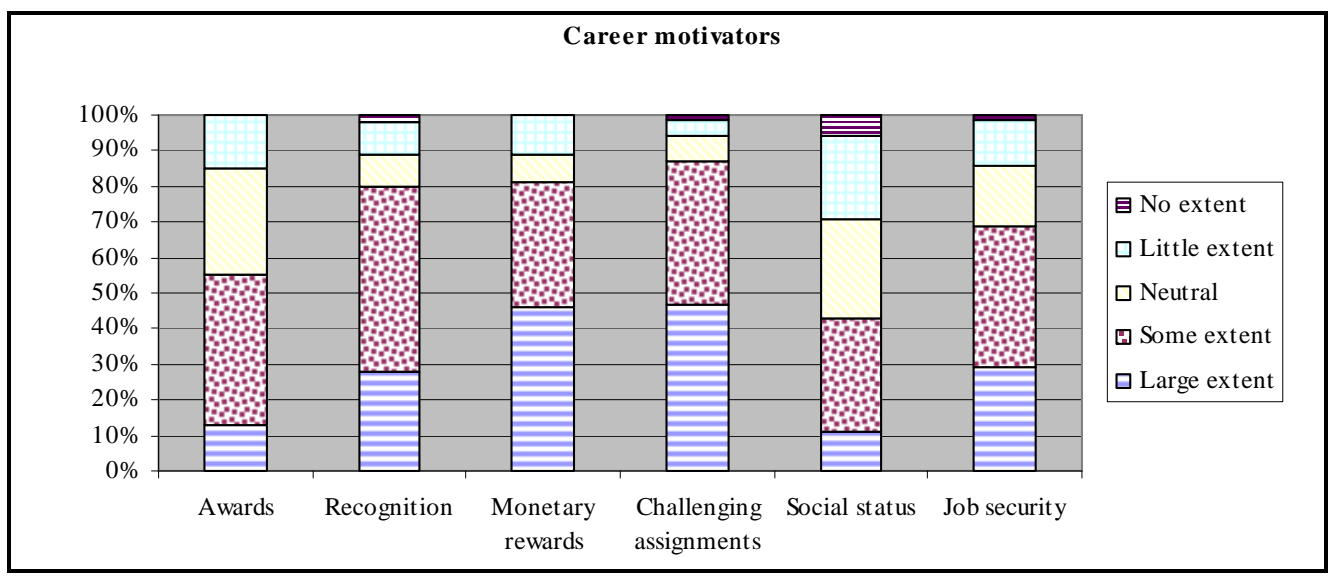


Figure 2 indicates that challenging work assignments, monetary rewards and recognition by peers are seen as very important career motivators. Recognition by peers is noted as an important motivator by Bergeron (2003:73), Defillipi, Arthur \& Lindsay (2006), Drucker (2002:259) and Thite (2004:33) and is seen as a career motivator to a large extent by 27 per cent of respondents. Monetary rewards are recognised by 45 per cent of respondents as a key career motivator (Myers, 1996:184) with 46 per cent of respondents seeing challenging work assignments as a motivational factor to a large extent and 40 per cent of respondents as a motivational factor to some extent in their careers (Dovey \& White, 2005:253; Mercer, 2008). Social status is considered the least important career motivator for these knowledge workers.

\subsubsection{Career readiness}

Table 3 indicates that 56.1 per cent of respondents totally agree and 37.8 per cent agree that technology is an important part of career readiness for knowledge workers. This finding supports the findings of Carter and Scarbrough (2001:216) that technology is an important part of knowledge management. The majority of the respondents (46.3 per cent) agree that they have created their own knowledge career strategies. Fifty percent of respondents agree that they have enough knowledge to start their careers, which may be a sign of overconfidence, as the skills and knowledge required by knowledge workers are continuously changing (Drucker, 2002:27).

\begin{tabular}{|c|c|c|c|c|c|}
\hline & \multicolumn{2}{|c|}{$\begin{array}{c}\text { Table } 3 \\
\text { Career readiness }\end{array}$} & \multirow[b]{2}{*}{ Neutral } & \multirow[b]{2}{*}{ Disagree } & \multirow[b]{2}{*}{$\begin{array}{l}\text { Totally } \\
\text { disagree }\end{array}$} \\
\hline & $\begin{array}{l}\text { Totally } \\
\text { agree }\end{array}$ & Agree & & & \\
\hline $\begin{array}{l}\text { I see new technology as beneficial to my } \\
\text { career }\end{array}$ & $56.1 \%$ & $37.8 \%$ & $3.7 \%$ & $2.4 \%$ & $0.0 \%$ \\
\hline I adapt to any challenges in my career & $40.2 \%$ & $57.3 \%$ & $2.4 \%$ & $0.0 \%$ & $0.0 \%$ \\
\hline $\begin{array}{l}\text { I feel that I am in charge of my own } \\
\text { knowledge career }\end{array}$ & $36.6 \%$ & $54.9 \%$ & $7.3 \%$ & $1.2 \%$ & $0.0 \%$ \\
\hline $\begin{array}{l}\text { I have created my own knowledge career } \\
\text { strategy }\end{array}$ & $25.6 \%$ & $46.3 \%$ & $18.3 \%$ & $8.5 \%$ & $1.2 \%$ \\
\hline $\begin{array}{l}\text { I have enough knowledge to kick off a } \\
\text { fulfilling career }\end{array}$ & $24.4 \%$ & $50.0 \%$ & $15.9 \%$ & $9.8 \%$ & $0.0 \%$ \\
\hline
\end{tabular}

\subsubsection{Career path}

Table 4 indicates that the need to become a specialist is very important to 48.8 per cent and important to 37.5 per cent of the respondents. According to No Doubt Research (2003:3) knowledge workers are highly specialised and loyal to their specific field of knowledge. Dual career ladders are very important to 31.3 per cent of the respondents. This finding correlates with the findings of Holman, Wall, Clegg, Sparrow and Howard (2003:146) and Petroni and Colacino (2008:22) on the importance of dual career ladders. Whilst still enabling knowledge workers to stay in a profession without becoming a manager the need for upward career growth is thus seen as an important career path for knowledge workers. Matching personal and organisational goals is very important to 42.9 per cent of the respondents which is indicative of knowledge workers to be motivated through task achievement, working towards organisational and personal goals (Kelly, 2007:126). The lack of importance attached to temporary work assignments by 42.5 per cent of respondents could be attributed to the economic downturn, or the lack of temporary work assignments available to knowledge workers in South Africa as discussed by McKenna (2006:11). 


\begin{tabular}{|c|c|c|c|c|c|}
\hline & \multicolumn{3}{|c|}{$\begin{array}{c}\text { Table } 4 \\
\text { Career path }\end{array}$} & \multirow[b]{2}{*}{ Unimportant } & \multirow[b]{2}{*}{$\begin{array}{l}\text { Very un- } \\
\text { important }\end{array}$} \\
\hline & $\begin{array}{c}\text { Very } \\
\text { important }\end{array}$ & Important & Neutral & & \\
\hline $\begin{array}{l}\text { Becoming a specialist in my field of } \\
\text { knowledge }\end{array}$ & $48.8 \%$ & $37.5 \%$ & $8.8 \%$ & $5.0 \%$ & $0.0 \%$ \\
\hline $\begin{array}{l}\text { Dual career ladders (managerial and } \\
\text { professional options) }\end{array}$ & $31.3 \%$ & $40.0 \%$ & $21.3 \%$ & $6.3 \%$ & $1.3 \%$ \\
\hline $\begin{array}{l}\text { Lifetime employment with a single } \\
\text { organisation }\end{array}$ & $3.8 \%$ & $6.3 \%$ & $32.5 \%$ & $41.3 \%$ & $16.3 \%$ \\
\hline $\begin{array}{l}\text { Matching my career goals with } \\
\text { organisational goals }\end{array}$ & $42.9 \%$ & $42.9 \%$ & $13.0 \%$ & $1.3 \%$ & $0.0 \%$ \\
\hline $\begin{array}{l}\text { A portfolio of multiple jobs with } \\
\text { different organisations over the } \\
\text { lifetime of my career }\end{array}$ & $15.0 \%$ & $40.0 \%$ & $32.5 \%$ & $10.0 \%$ & $2.5 \%$ \\
\hline $\begin{array}{l}\text { Temporary work assignments } \\
\text { followed by short periods of } \\
\text { unemployment }\end{array}$ & $1.3 \%$ & $11.3 \%$ & $23.8 \%$ & $21.3 \%$ & $42.5 \%$ \\
\hline
\end{tabular}

\subsubsection{Career strategy}

Figure 3 indicates that knowledge workers feel responsible for their own careers and that they actively try to manage their careers through networking, gaining experience and continuous learning. 39 per cent of respondents indicated to a very large extent the most important career strategy as the continuous learning of new skills, while 46 per cent of the respondents indicated this to a large extent. Such a strategy should result in knowledge workers reaching their long-term career goals (Marcus \& Watters, 2002:91; Stokely, 2008:49). Only 42 per cent of the respondents consult mentors to a large extent and 22 per cent to a very large extent. Knowledge workers need mentoring to ensure that knowledge sharing occurs and that an opportunity is provided for the individual being mentored to convert experience into knowledge (Harman \& Brelade, 2000:73).

The least important career strategy is seen as building a network of contacts, which is something knowledge workers need to take note of, as Myers (1996:52) claims that the development of social networks is critical in boundaryless careers in order to add more value to organisations.

Figure 3

Career strategy

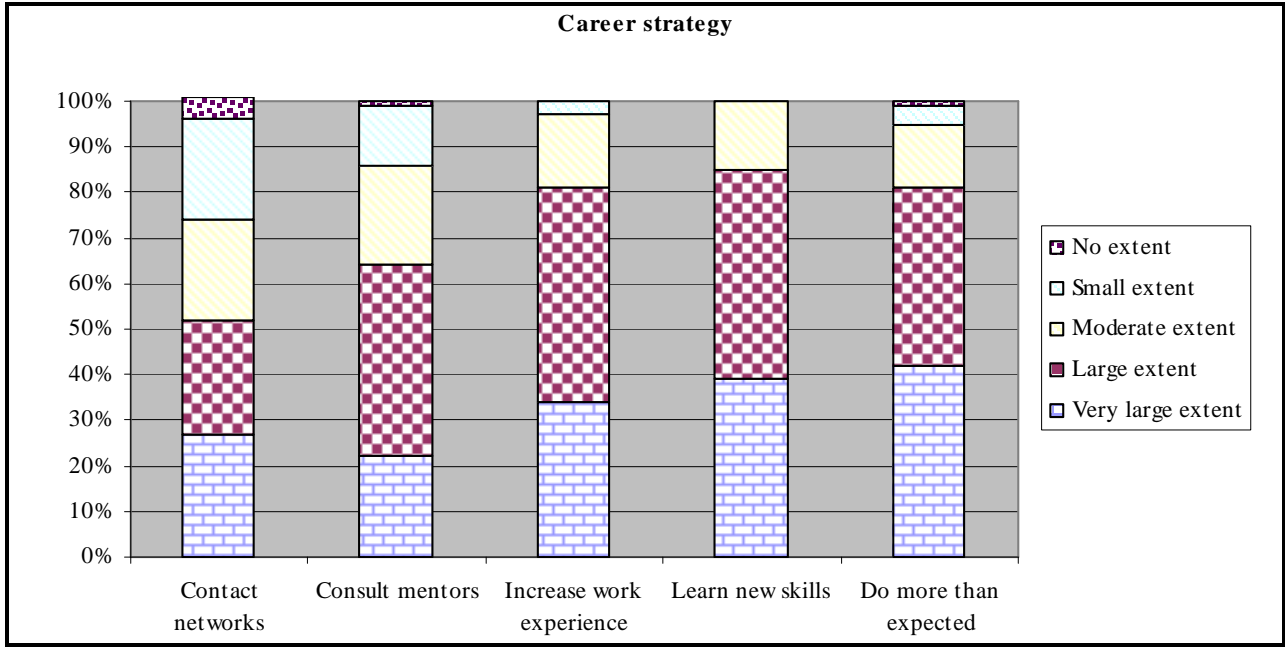




\subsubsection{Satisfaction experienced as a knowledge worker}

The descriptive statistics related to the satisfaction experienced in the careers of knowledge workers are shown in Table 5. Most knowledge workers feel that they achieve a sense of accomplishment and this finding is related to the findings of Dovey and White (2005:253). Forty percent of the respondents are very satisfied with their flexible work conditions, which corresponds well to the requirements placed on knowledge workers by the new boundaryless career (Lee-Kelly et al., 2007:204; Marcus \& Watters, 2002:92; Thite, 2004:37; Tomlinson:153). The majority of respondents (36.3 per cent very satisfied and 47.5 per cent satisfied) indicate that they work on challenging assignments or projects. The results indicate that knowledge workers are in fact satisfied with their careers to a large extent, yet certain areas are to be looked at in order to ensure knowledge workers stay motivated. Table 5 indicates that 46.2 per cent of knowledge workers are satisfied with their careers to date, with 19.2 per cent being very satisfied. This means that organisations should create a work environment that is aligned with the expectations of knowledge workers to allow them to achieve job satisfaction (Wong, 2005:273).

Table 5

Satisfaction experienced as a knowledge worker

\begin{tabular}{|c|c|c|c|c|c|}
\hline & $\begin{array}{c}\text { Very } \\
\text { satisfied }\end{array}$ & Satisfied & Neutral & Dissatisfied & $\begin{array}{c}\text { Very } \\
\text { dissatisfied }\end{array}$ \\
\hline A sense of accomplishment & $41.3 \%$ & $40.0 \%$ & $12.5 \%$ & $5.0 \%$ & $1.3 \%$ \\
\hline Flexible working conditions & $40.0 \%$ & $38.8 \%$ & $15.0 \%$ & $6.3 \%$ & $0.0 \%$ \\
\hline $\begin{array}{l}\text { The contributions made by you as } \\
\text { a knowledge worker }\end{array}$ & $37.5 \%$ & $48.8 \%$ & $7.5 \%$ & $6.3 \%$ & $0.0 \%$ \\
\hline $\begin{array}{l}\text { Working on challenging } \\
\text { assignments or projects }\end{array}$ & $36.3 \%$ & $47.5 \%$ & $13.8 \%$ & $2.5 \%$ & $0.0 \%$ \\
\hline $\begin{array}{l}\text { Opportunities for career } \\
\text { advancement }\end{array}$ & $30.0 \%$ & $37.5 \%$ & $20.0 \%$ & $5.0 \%$ & $7.5 \%$ \\
\hline $\begin{array}{l}\text { Being rewarded for your } \\
\text { knowledge }\end{array}$ & $21.3 \%$ & $46.3 \%$ & $17.5 \%$ & $12.5 \%$ & $2.5 \%$ \\
\hline $\begin{array}{l}\text { Being promoted based on what } \\
\text { you know }\end{array}$ & $20.0 \%$ & $55.0 \%$ & $15.0 \%$ & $7.5 \%$ & $2.5 \%$ \\
\hline Career progress to date & $19.2 \%$ & $46.2 \%$ & $21.8 \%$ & $10.3 \%$ & $2.6 \%$ \\
\hline
\end{tabular}

6

\section{Recommendations}

Lifelong careers with one organisation are a thing of the past. Knowledge workers are more concerned with lifelong learning in a succession of jobs in order to gain the experience necessary to provide the organisation with a competitive advantage. The majority of the respondents are employed at their current organisation for less than three years. The movement of knowledge workers in a knowledge economy between organisations correspond to the nature of modern careers, which can be seen as a sequence of jobs or projects over the course of a person's life. Knowledge workers therefore take control of their own careers, as their careers consist of a series of projects or assignments, irrespective of the organisation employing them.

Knowledge workers are more aware of the challenges posed by modern careers and they are better prepared to enter their careers and ensure further development. It is very important for the majority of respondents to match their personal career goals with organisational goals in order to stay motivated in their careers. Matching individual and organisational goals are dependent on trust between knowledge workers and the organisation if this level of alignment is to be achieved. Being able to match personal goals with organisational goals generates a sense of accomplishment for knowledge workers, 
which is required to build a fulfilling career. The necessity for good communication skills need to be understood by organisations in order to use these knowledge workers to generate a competitive advantage as communication, forms a considerable part of the work that knowledge workers perform.

Knowledge workers require more knowledge to be effective in their jobs as the amount of knowledge keeps increasing. The need for knowledge workers who are able to deal with large amounts of knowledge in South Africa is acknowledged by the respondents. Respondents confirmed that the use of knowledge provides them with a competitive advantage in the knowledge economy. Knowledge workers use temporary assignments as part of career preparation, yet the respondents indicated that they are not interested in short work assignments. The underlying reason may be due to the fact that the respondents are mostly employed as full time workers, yet the lack of interest in temporary assignments may lead to a loss of opportunity for knowledge workers entering their careers.

Lifelong learning throughout the career of a knowledge worker is essential to stay competitive and deliver value to the organisation. The acknowledgement of lifelong learning by the respondents is indicative of the value placed upon learning over the course of a knowledge worker's career. Lifelong learning provides knowledge workers the ability to gain access to better positions over the course of a career. Personal development is the responsibility of each knowledge worker. Managing their careers leads to better motivation and ultimately an increase in organisational performance. Personal development also leads to a sense of achievement, providing personal and professional growth. However, internal training is rarely seen as a means for gaining more knowledge by the respondents and could be an indication that South African organisations do not invest in knowledge workers or that knowledge workers do not attach a lot of value to internal training. South African organisations need to assess their internal training and development programmes if they are to deliver any value to knowledge workers. Organisations should ensure that their training programmes are innovative to ensure that they respond to the demands of the knowledge economy.

Mentoring is an area of concern as the respondents indicated that they are not keen to consult mentors in their field of specialisation (see Figure 3). This is in stark contrast to literature, which notes that knowledge workers need mentoring to ensure that knowledge sharing occurs in order to ensure a successful entry into the job market.

Awards, recognition from peers, money, challenging work assignments and status are all considered important career motivators for knowledge workers. Money is still considered to be a primary career motivator by the respondents. Organisations need to take note of their reward structures, as knowledge workers have indicated that although knowledge gives them a competitive advantage in the knowledge economy, promotions and rewards based on their knowledge are insufficient. Informal measures such as recognition are also starting to become more important for knowledge workers and should be used in conjunction with the traditional measures to ensure that knowledge workers achieve a sense of career progress. Respondents also consider autonomy important, in order to control the tasks assigned to them within their organisation. Knowledge workers thus strive to create their own work environment. This is descriptive of the level of satisfaction that knowledge workers experience throughout their careers. A sense of accomplishment reduces feelings of boredom associated with repetitive and less challenging tasks. Challenging tasks generates the sense of accomplishment needed in order to create a fulfilling career. Providing knowledge workers with a series of challenging work assignments allows them to develop their careers through such assignments.

\section{7}

\section{Conclusion}

This article aims to investigate the issues and aspects related to career development of knowledge workers in South Africa. The career issues affecting knowledge workers were established through an online survey, 
providing a view on the autonomy, rewards, training and progress experienced by knowledge workers in their careers. Knowledge workers play an increasingly important part in the knowledge economy and contribute to the competitive advantage and future potential of organisations. The impact made by knowledge workers on the knowledge economy has prompted management to take note of the key issues affecting knowledge workers throughout their careers. The major findings linked to the literature consulted indicated that even though knowledge workers require more knowledge just to enable them to perform their jobs, their knowledge still provides them with a competitive advantage in their careers and the knowledge economy. Knowledge workers furthermore acknowledged that they are personally responsible for their own career development and attempt to ensure that they take part in lifelong learning and training.

\section{References}

ALLEY, L. 1999. Diverting a crisis in global human and economic development: a new transnational model for lifelong continuous learning and personal knowledge management, Higher Education in Europe, 24(2):187-195.

BERGERON, B. 2003. Essentials of knowledge management, New Jersey: John Wiley \& Sons. BONTIS, N. 2001. CKO Wanted - evangelical skills necessary: a review of the chief knowledge officer position, Knowledge and Process Management, 8(1):29-38.

CARTER, C. \& SCARBROUGH, H. 2001. Towards a second generation of KM? The people management challenge, Education + Training, 43(4/5). [Online] Available from Emerald: http://www.emeraldinsight.com [Accessed 2008-02-10].

COOPER, D.R. \& SCHINDLER, P.S. 2003. Business research methods $\left(8^{\text {th }}\right.$ ed.) New York: McGraw-Hill. CURRIE, G., TEMPEST, S. \& STARKEY, K. 2006. New careers for old? Organizational and individual responses to changing boundaries. International Journal of Human Resource Management, 17(4):755-774. [Online] Available from EBSCO Host: http://search.global.epnet.com [Accessed 2009-03-09].

DEFILLIPPI, R.J., ARTHUR, M.B. \& LINDSAY, V.J. 2006. Knowledge at work. Oxford: Blackwell.

DENG, P.S. Applying a market-based approach to the development of a sharing-enabled KM model for knowledge-intensive small firms, Information Systems Management, 25(2):174-187.

DOVEY, K. \& WHITE, R. 2005. Learning about learning in knowledge-intense organisations, The Learning Organisation, 12(3):246-260.

DRUCKER, P. 1999. Knowledge-worker productivity: the biggest challenge, California Management Review, 41(2):79-94.

DRUCKER, P. 2001. The essential drucker. Oxford: Butterworth-Heinemann.

DRUCKER, P. 2002. Managing in the next society. Oxford: Butterworth-Heinemann.

EFIMOVA, L. 2003. Knowledge worker paradox, The Knowledge Board. [Online] Available at: http://www.knowledgeboard.com/item/119378 (Accessed 16 June 2008).

EVANS, C. 2003. Managing for knowledge - HR's strategic role. Oxford: Butterworth-Heinemann. GOTTSCHALK, P. 2005. Strategic knowledge management technology. Idea Group: Hersey.

HARMAN, C. \& BRELADE, S. 2000. Knowledge management and the role of HR: securing competitive advantage in the knowledge economy. London: Prentice Hall.

HIGGINS, J. \& TAPP, R. 2008. Learning when to outsource learning, Chief Learning Officer, 7(2):32-37. HOLMAN, D., WALL, T.D., CLEGG, C.W., SPARROW, P. \& HOWARD, A. 2003. The essentials of the new workplace. West Sussex: Wiley.

KELLY, C. 2007. Managing the relationship between knowledge and power in organisations, Aslib Proceedings: New Information Perspectives, 59(2):125-138.

LIN, C., KUO, T., KUO, Y., HO, L. \& KUO, Y. 2008. The KM chain - empirical study of the vital knowledge sourcing links, Journal of Computer Information Systems, 48(2):91-99.

MARCUS, R. \& WATTERS, B. 2002. Collective knowledge: intranets, productivity, and the promise of the knowledge workplace. Washington: Microsoft Press. 
MCGREGOR, J., TWEED, D., PECH, R. 2004. Human capital in the new economy: devil's bargain?, Journal of Intellectual Capital, 5(1):153-164.

MCKENNA, C.D. 2006. The world's newest profession - management consulting in the twentieth century. New York: Cambridge University Press.

MERCER. 2008. Brainpower: rewarding knowledge workers. [Online] Available at: http://www.mercer.com/referencecontent.htm?idContent=1314145 [Accessed 2009-03-09]

MYERS, P.S. 1996. Knowledge management and organisational design. Massachusetts: ButterworthHeinemann.

NO DOUBT RESEARCH. 2003. Knowledge management and the knowledge worker. [Online] Available at: http://www.nodoubt.co.nz/articles/knowledgeworker.pdf [Accessed 2009-03-13].

NONAKA, I. \& TEECE, D. 2001. Managing industrial knowledge: creation, transfer and utilization. London: SAGE.

PATON, S. 2005. In search of the knowledge worker, Working paper Labour Process Conference. [Online] Available at: www.hrm.strath.ac.uk/ILPC/2005/conf-papers/Paton.pdf [Accessed 2009-03-09].

PETRONI, A. \& COLACINO, P. 2008. Motivation strategies for knowledge workers: evidences and challenges, Journal of Technology Management and Innovation, 3(3):21-32.

PRINGLE, J.K. \& MALLON, M. 2003. Challenges for the boundaryless career odyssey, International Journal of Human Resources Management, 14(5):839-853.

SCHELL, W.J. 2008. Building a knowledge management framework to overcome the challenges of developing engineering teams in financial services, Engineering Management Journal, 20(1):3-9.

SMITH, C. 2008. Get SA out of BEE trouble. [Online] Available at:

http://www.fin24.com/articles/default/display_article.aspx?ArticleId=1518-1786_2318068 [Accessed 200903-09].

STANKOSKY, M. 2005. Creating the discipline of knowledge management. New York: Elsevier Butterworth-Heinemann.

STOKELY, S. 2008. Shiny happy people, Intheblack. 78(1):46.

STOVEL, M. \& BONTIS, N. 2002. Voluntary turnover: knowledge management - friend or foe?, Journal of Intellectual Capital, 3(3):303-322.

SVETLIK, I. \& STAVROU-COSTEA, E. 2007. Connecting human resources management and knowledge management, International Journal of Manpower, 28(3/4):197-206.

TEMPLER, A.J. \& CAWSEY, T.F. 1999. Rethinking career development in an era of portfolio careers, Career Development International, 4(2):70-76.

THITE, M. 2004. Strategic Positioning of HRM in Knowledge-based Organizations, The Learning Organization, 11(1):28-44.

TOMLINSON, M. The Career Trajectories of Knowledge Workers, Organisation for Economic Co-operation and Development. [Online] Available at: www.oecd.org/dataoecd/35/9/2101026.pdf [Accessed 2009-03-13]. VAN TONDER, J. 2007. Staat se gesloer laat ekonomie ver agter raak, Sake Rapport. [Online] Available at: http://www.solidaritysa.co.za/Tuis/wmview.php?ArtID=997 [Accessed 2009-03-09].

WADDOCK, S. 2007. Leadership integrity in a fractured knowledge world, Academy of Management Learning \& Education, 6(4):543-557.

WONG, K.Y. 2005. Critical success factors for implementing knowledge management in small and medium enterprises, Industrial Management \& Data, 105(3):261-279.

YANG, I. \& LEE, S. 2009. Career development of female knowledge workers in knowledge-based industries, Women's Studies Forum. [Online] Available at: www.kwdi.re.kr/data/04forum-6.pdf [Accessed 2009-03-13].

ZACK, M.H. 1999. Knowledge and strategy. Boston: Butterworth-Heinemann.

ZIKMUND, W.G. 2003. Business research methods. Ohio: Thomson South-Western. 